\title{
Mogens N. Pedersen \\ Klarer han pynten? \\ Logitmetoden mellem forenklingens Scylla og realiteternes Charybdis
}

Ved forsvaret af Søren Risbjerg Thomsens afhandling Danish Elections 1920-79 - A Logit Approach to Ecological Analysis fremførte jeg ex auditorio nogle betragtninger om den foreslåede nye metode og dens validitet. Det mundtlige indlæg blev publiceret i dette tidsskrifts tredje hæfte i 1987 under titlen "Skyggebilleder? - Nogle kommentarer til validitetsdiskussionen omkring Søren Risbjerg Thomsens metode til økologisk inferens «. Nu følger så en opfølgende kritik med en ligeledes metaformættet titel.

Mine bemærkninger dengang faldt i to dele: en positivt rosende del, men også en mere forbeholden, kritisk del.

De positive aspekter, der blev fremhævet, var dels emnets centrale betydning for studiet af politik, dels satsningens dristighed. Jeg omtalte også de implicitte muligheder og løfter, som metoden synes at indebære for analysen af andre fænomener end vælgeradfærd. I den forbindelse skitserede jeg, hvorledes man ved at sætte de estimerede vælgerbevægelser i relation til andre fænomener (blandt andet partistørrelse og aggregeret vælgerflygtighed) kunne få øje på interessante og intuitivt plausible sammenhænge. Denne iagttagelse kunne i sig selv siges at udgøre en indirekte - om end svag - støtte for en påstand om metodens validitet.

Disse positive bemærkninger ville jeg skrive under på den dag i dag. Logitmodellen må stadig betragtes som en betydelig forskningsmæssig indsats - en konstatering, der også bekræftes af den interesse, den har vakt uden for Danmarks grænser.

Hovedærindet $\mathrm{i}$ oppositionen var imidlertid at påpege, at præses endnu ikke havde sandsynliggjort, at den nye metode til økologisk inferens besad en tilfredsstillende grad af validitet.

Udgivelsen af samleværket Modern Political Ecological Analysis afstedkommer et gensyn med problematikken, herunder også med den ved disputatsforsvaret fremførte kritik. Bør denne kritik fastholdes, eller er der sket noget, der gør det rimeligt eller nødvendigt at modificere den ret så skarpe vurdering fra dengang?

Her må det dog indledningsvis straks fastslås, at ét er, at den nye bog kan danne udgangspunkt for en fornyet drøftelse af validitetsproblemet. Det er ikke det samme som at sige, at udgangspunktet er optimalt. Efter min opfattelse foreligger en fuldt tilfredsstillende afprøvning først, når metoden uden held er blevet forsøgt falsificeret af andre forskere fra den internationale kreds af vælgeradfærdsforskere. I så henseende kan den nye bog ikke leve op til kravene allerede af den 
grund, at det er metodens ophavsmand, der selv forestår og/eller medvirker ved afprøvningen. Man må derfor fastslå, at diskussionen i den nye bog i nogen grad har karakter af et partsindlæg.

\section{Rekapitulation af kritikken}

Man bør ikke gentage sig selv, men her finder jeg dog grund til at gentage hovedpunkterne i min oprindelige kritik. For det første fordi Søren Risbjerg Thomsen mig bekendt aldrig direkte og på tryk har svaret - at han har taget kritikken til sig, kan den opmærksomme læser af bogens centrale kapitel om validitetsproblemet dog ikke undgå at bemærke. For det andet kan der være kommet nye læsere til siden sidst. Tillad mig derfor et kort resumé. Min oprindelige kritik kan sammenfattes i tre punkter.

(1) Da det, der skal måles, in casu de faktisk forekommende vælgerbevægelser fra ét valg til det næste, aldrig vil kunne blive fuldstændig kendt, er det principielt umuligt at vurdere estimaternes såkaldt interne validitet. Estimaterne er at betragte som en art "skyggebilleder " af de sande bevægelser - på samme måde som man også må karakterisere selv den smukkeste vandringsmatrice fra en survey-undersøgelse. Det bedste, forskeren kan gøre, er at søge at overbevise skeptiske kolleger om, at der eksisterer en form for isomorfi mellem estimationsmetodens præmisser og de holdnings- og adfærdsmæssige præmisser for vælgeradfærden. Et sådant forsøg gjorde Søren Risbjerg Thomsen ikke i sin disputats.

(2) Da Søren Risbjerg Thomsen valgte at benytte to i sig selv ret tvivlsomme danske surveymaterialer som grundlag for sin egen validitetstestning, var det heller ikke på det foreliggende grundlag muligt at sige noget holdbart om metodens eksterne validitet. De to materialer var dels det på grund af en ringe besvarelsesprocent validitetsmæssigt problematiske "akademiske" panel-survey fra 1971-73 og dels en kommerciel undersøgelse fra 1973, indsamlet på et sub-optimalt tidspunkt før valget.

(3) En af mig selv foretaget sammenligning mellem et antal OBSERVA-materialer og de af Søren Risbjerg Thomsen estimerede vandringsmatricer fra perioden 1971-79 viste store uoverensstemmelser, hvilket også måtte føre til den konklusion, at man på det foreliggende grundlag ikke kunne finde støtte for en påstand om logitmetodens validitet - men heller ikke for det modsatte, idet de pågældende data i sig selv kunne tænkes at være dubiøse.

\section{Kritikkens imødegåelse}

De for mig i denne forbindelse afgørende spørgsmål er derfor, om Søren Risbjerg Thomsen, for det første, har formået at argumentere mere overbevisende for metodens interne validitet og, for det andet, har forbedret den eksterne validering gennem succesfuld sammenligning med andre og bedre survey-materialer?

Når det drejer sig om metodens interne logik og graden af isomorfi med "virkeligheden ", således som vi mener at kende denne "virkelighed " fra årtiers empiriske valg- og vælgeradfærdsforskning - så er der ikke særlig meget at hente i den nye bog, hvor man primært har satset på at begrunde logitmetodens eksterne validitet. Søren Risbjerg Thomsen skjuler ikke, at begrundelsen for valget af model- 
lens to centrale forudsætninger ikke er disses grad af realisme, men det forhold, at de er simple, og at de gør det let at foretage økologisk inferens. Dog må det hilses med glæde, at der nu foretages en klar sondring mellem de tre sæt værdier, der ideelt set bør sammenlignes: vælgerbevægelsens sande værdier, surveyestimaterne og de økologiske estimater. Der opstilles også i et teoretisk-statistisk appendix et sæt betingelser for, at sidstnævnte estimater kan betragtes som valide i forhold til surveyestimaterne. Disse betragtninger sammen med indførelsen af en ny iterativ tilpasningsprocedure, der fører til bedre sammenlignelighed mellem datasættene, må betragtes som et forsøg på at komme noget af den oprindelige kritik i møde. Mindre positivt er det, at Søren Risbjerg Thomsen fortsætter med at benytte de oprindelige danske datasæt som udgangspunkt for validitetsdiskussionen. Heldigvis har han i denne omgang også inddraget flere danske materialer, end tilfældet var i den oprindelige afhandling. Det drejer sig dels om nogle OBSERVA-data (vandringsmatricer baseret på panelsurveys), og dels om to recallsurveys, nemlig et af TVA i 1971 indsamlet materiale fra tre valgsteder samt det akademiske survey fra 1975. Hovedforfatterens uvane tro undergives ingen af disse datasæt en (kilde)kritisk diskussion. De bruges bare - kritikløst med andre ord.

Når disse nye data lægges til grund, og når der yderligere foretages den omtalte iterative transformation, bliver billedet ganske speget. Populært sagt falder de forskellige sammenligninger mellem surveydata og økologiske estimater og mellem surveymaterialerne indbyrdes ikke ud, som man kunne forvente - og håbe. Det ser således ikke ud til, at metodens validitet har vundet yderligere støtte i det danske materiale. Logitmetoden synes af uforklarlige grunde at give bedre resultater i Finland - og til dels i Sverige - end i Danmark. Det er fint at konstatere, at forskerne ikke søger at feje problemerne ind under gulvtæppet. Deres konstatering af validitetsproblemets fortsatte eksistens leder dem dog ud på de vilde vover, når de antyder muligheden af at foretage en landespecifik tilpasning af den generelle model. Dette er en farlig tankegang. Hvis den blev udført, ville konsekvensen være, at man fratog metoden dens væsentligste kvaliteter, nemlig simpelhed og generalitet.

\section{Konklusion}

Et sted i bogen glæder forfatterne sig over den stærke lighed mellem et økologisk estimat og det tilsvarende, af Bo Särlvik indsamlede, surveymateriale fra det svenske 1968-valg. Det siges endda (s.75), at ligheden er "så slående, at det er svært at sige, hvad der validerer hvad. "Store ord, må man sige, hvis man da ikke vil kalde udsagnet absurd.

Logitmetodens entusiastiske forkæmpere er endnu ikke nået så langt i valideringsprocessen, at de kan tillade sig at sætte den nye metode forrest, endsige give dårlige karakterer til gængs surveymetodik. Dertil mangler der endnu en del. På den anden side har anvendelsen af metoden på svenske og finske data ført til interessante resultater - og i et vist omfang også til estimater, der virker mere overbevisende end tidligere forsøg på at foretage økologisk inferens. Dertil kommer, at metodens anvendelse i de tre lande, herunder altså også i Danmark, giver plausible 
estimater på historiske materialer fra tiden før surveymetodikkens indførelse. Men sligt kan jo ikke afgørende bekræfte den nye metodes anvendelighed.

Hvad skal der til yderligere, førend skeptikeren bliver helt overbevist? Først og fremmest uafhængig afprøvning på absolut førsteklasses surveymaterialer, gerne fra partisystemer med forskellige formater: forskellige former for to-partisystemer samt flerpartisystemer med varierende fordeling af vælgerne på partier. Man kunne ideelt ønske sig, at logitmetoden blev afprøvet på data fra USA, UK, Frankrig og Holland, lande som alle har en stærk tradition for såvel surveybaseret som økologisk baseret valgforskning. Og så ville det da i øvrigt være fint, om Søren Risbjerg Thomsen ville tage sig tid til på mere populær måde at diskutere sin metodes erkendelsesmæssige præmisser og herunder sandsynliggøre, hvorfor netop logitmetoden forbavsende nok synes at efterligne virkelighedens valgresultater helt pænt, selv om han bevidst har valgt at lade metoden bygge på præmisser, der ser noget virkelighedsfjerne ud. Det er jo ikke alle valgforskere, der er tilfredse, når blot en models forudsigelser er akkurate. Der er faktisk en del, der også lægger vægt på, at de bag modellen liggende antagelser er realistiske.

Er pynten klaret? Endnu ikke, men udsigterne er fortsat lyse! 